FESIOE

Fundación Emilio Soldevilla para la Investigación y Desarrollo
de la Economia de la Empresa journal homepage: http://www.ehu.eus/cuadernosdegestion/revista/es/

ISSN: 1131-6837 / e-ISSN: 1988-2157

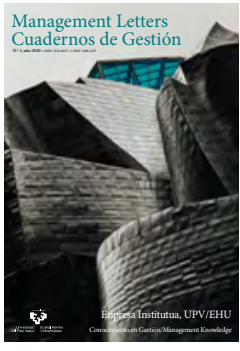

\title{
Introduction to the Special Section: Tourism \& Leisure
}

\section{Introducción a la Sección Especial: Turismo \& Ocio}

\author{
Inés Küster ${ }^{\mathrm{a}}$ \\ a University of Valencia. Faculty of Economics. Ava Tarongers s/n, 46022, Spain. ines.kuster@uv.es. https://orcid.org/0000-0002-8688-9175
}

A R T I C L E I N F O

DOI: $10.5295 /$ cdg.201414ik
As Han, Kim and Hyun (2011) point out, companies in tourism \& leisure industry strive to create a unique visitors' experience by improving their service quality to retain international guests. Regardless of the type of tourism and leisure activity in question, the aim of tourism \& leisure industry is to get visitors to a destination or event and ultimately get their loyalty (Jeaheng, Al-Ansi and Han 2020). In order to reach this objective, academics have studied those key aspects that can influence the visit to a certain destination or event. In this sense, in this special issue, diverse research has been presented. These papers are not alien to the development of new technologies and how they can help the intentions of visiting a destination.

In this context, and following previous works (i.e. Rather, Tehseen, Itoo and Parrey 2019), some key concepts underlie as a common fundamental basis in several papers. Concepts such as satisfaction, quality, trust or commitment are revealed as clear antecedents to the intention of visitors. For example, in the article entitled "Increase the influence of the travel video bloggers by using Youtube to sell trips indirectly through relationship marketing and service quality online", Sarmiento, De Esteban and Antonovica, with a sample of 1245 young university students, focus on the relationship between the e-service quality provided by travel youtubers and e-relationship quality with users, formed by trust, satisfaction and commitment. Their results show that dimensions of quality of service (information and communication) are the ones that affect the most in the development of the quality of relation. The authors propose that relationship quality must be defined as a multi-dimensional construct where trust, satisfaction and commitment must be the main dimensions that may be influenced from it (acting as an antecedent) or may be admitted of other dimensions (acting as consequents).

Ballina, Valdés and Del Valle, in their article entitled "Quality marks as an economic consolidation factor for rural tourism", also center their efforts on analyzing the determinants of quality, as an antecedent to visitor's loyalty. These authors review the literature on the perceived benefits of quality standards, paying particular attention to rural accommodation. They use data from the "Demand Survey": an annual survey of the directors of the hotels from 2005 to 2015 , considering only the rural hotels of categories 1, 2 and 3 stars with the rural quality brand "Casonas Asturianas". Their results show that quality certificates are signs of differentiation that customers value and allow to avoid the use of price as a promotional tool. As the authors state their results provide evidence about the relationship between the quality rural standard and the rural hotels' economic performance. Additionally, their conclusions indicate the presence of some distinctions in the self-selection bias, explicitly referring to high season tariffs. 
Related to price, specifically non-monetary price, the paper entitled "Non monetary price perceived in e-peer-to-peer accommodation. Airbnb guests' perspective, authored by Küster and Pascual focuses on 136 Airbnb guests. The authors state that although monetary price is a key variable in predicting buying behavior, non-monetary also can play a determinant role. Their results show that past experience, financial risk, and time risk influence the non-monetary perceived price, and this price and past experience affect guest intentions.

Related to leisure industry, Pérez-Gálvez, López-Guzmán, Gómez-Casero and Medina-Viruel, with a sample of 305 attendees to the QurtubaJazz Festival in Córdoba, emphasize the importance of motivations, satisfaction and loyalty. The conclusions of this article, entitled "Satisfaction and loyalty in musical festivals. Study based on the level of jazz musical knowledge" stand out the existence of different patterns regarding satisfaction and loyalty according to the knowledge of the attendees about the different genres of Jazz. The authors highlight the important role of cultural motivations as a differentiating character that could affect intention to re-visit the festival.

This Special Section also includes a more methodological article, entitled "Methodological elements to design a city branding with the use of grounded theory" that analyzes the key elements to build a city branding, using the Grounded Theory and a qualitative approach. As Torres-Zamudio, González-Castro and Manzano-Durán underline, their proposal offers a precise definition of specific city branding and established strategic planning, management environment, and fundamental branding structure as those key founding elements for any particular city branding. This paper presents an advance in line with the work of Chen, Zhou, Zhan and Zhou (2020) that underlines the importance to focus on brand destination in order to influence revisit and recommendation intentions.

\section{References}

Chen, R., Zhou, Z., Zhan, G., \& Zhou, N., 2020. The impact of destination brand authenticity and destination brand self-congruence on tourist loyalty: The mediating role of destination brand engagement. Journal of Destination Marketing \& Management, 15, 100402.

Han, H., Kim, W., \& Hyun, S. S., 2011. Switching intention model development: Role of service performances, customer satisfaction, and switching barriers in the hotel industry. International Journal of Hospitality Management, 30(3), 619-629. doi:10.1016/j. ijhm.2010.11.006

Jeaheng, Y., Al-Ansi, A., \& Han, H., 2020. Impacts of Halal-friendly services, facilities, and food and Beverages on Muslim travelers' perceptions of service quality attributes, perceived price, satisfaction, trust, and loyalty. Journal of Hospitality Marketing \& Management, $1-25$.

Rather, R. A., Tehseen, S., Itoo, M. H., \& Parrey, S. H., 2019. Customer brand identification, affective commitment, customer satisfaction, and brand trust as antecedents of customer behavioral intention of loyalty: An empirical study in the hospitality sector. Journal of Global Scholars of Marketing Science, 29(2), 196-217. 